\title{
APPLICATION POSSIBILITIES OF VEGETABLE AND PREBIOTIC COMPONENTS IN FERMENTED MILK PRODUCTS
}

\author{
Marina Slozhenkina ${ }^{1,2}$, Olga Druker ${ }^{3}$, Vera Kryuchkova ${ }^{3}$, Elena Zlobina ${ }^{1,4}$ \\ ${ }^{1}$ Volga Region Research Institute of Manufacture and Processing of Meat-And-Milk Production, \\ Russia; ${ }^{2}$ Volgograd State Technical University, Russia; ${ }^{3}$ Don State Agrarian University, Russia; \\ ${ }^{4}$ Volgograd State University, Russia \\ slozhenkina@mail.ru,olgadruker@ya.ru,kverav@yandex.ru, elenazlobina2008@yandex.ru
}

\begin{abstract}
The article justified expediency of the use in the formulation of symbiotic fermented milk product unconventional phytocomponents and syrup of lactulose, developed the technology of production based on the thermostatic method, conducted comprehensive assessment of the consumer appeal on the basis of studying of sensory properties, physicochemical, microbiological indicators, vitamin, mineral and amino acid composition. The influence of the starter microflora in the process of acid in the produced samples experimentally determined the optimal ways of preliminary preparation of restealing components, set dose, the technological stage of their making into the prepared liquid phase and their effect on the quality parameters of these products. We have found a significant increase in the content of essential amino acids in the enriched sample as compared to the traditional formulation, a mass fraction of carbohydrates, minerals and vitamins that is due to the high content of vegetable raw materials. Besides that, the mass fraction of the protein symbiotic product slightly exceeded the value of the control sample. The number of lactic acid microorganisms in the enriched sample exceeds as standardized, and the importance of the traditional fermented milk product, which indicates the high physiological value of the developed product. Enrichment of the fermented milk product with the proposed functional components increased its nutritional and biological values. The developed product has functional activity in relation to prevention of alimentary conditions of the human body, which is very important at the present time. The enriched milk product possesses high consumer properties, what makes it possible to predict the customer demand among the population in the future.
\end{abstract}

Keywords: dairy products, leaven, technology, consumer properties, functional food.

\section{Introduction}

One of the most important challenges in decisions of food security and nutrition questions and achieving the sustainable development goals is the elimination of all forms of malnutrition [1]. In 2016, the beginning of the UN Decade of action on nutrition (2016-2025) started.

Malnutrition ranges from severe undernutrition to overweight and obesity. It affects populations throughout the lifecycle, from conception through childhood, into adolescence, adulthood and older age. Malnutrition may be a reflection of deficiencies in macronutrients (carbohydrates, fats or proteins) or micronutrients (vitamins and minerals). Furthermore, the diversification and development of the production of enriched, specialized, functional, therapeutic and preventive food products is one of the most important directions and means of optimizing nutrition and improving the health of the population [2]. Particularly relevant is the problem in the area of power optimization and the development of food technology aimed at prevention of a number of nutritional diseases such as protein-energy and protein deficiency, iron deficiency anemia, iodine and iron deficiency diseases, hypo- and avitaminosis, alimentary obesity, etc. [3]. The diet of modern man is characterized by an excessive content of animal fat and easily digestible carbohydrates, which, along with sedentary lifestyle, is the cause of overweight and obesity, which in turn are one of the main causes of hypertension. The likelihood of developing the initial arterial hypertension is 50-70\% higher among people suffering from obesity, and it is not only the excessive amount of adipose tissue, but a complex set of metabolic disorders [4]. Scientists have proved the relationship status of the intestinal microflora with the problem of obesity, and as a result, the development of hypertension [5]. To effectively deal with excess weight and hypertension one can only in the case when the bowel is in order. After all, once the microbial balance is disturbed, the formation of cholesterol plaques the vessels lose their elasticity, and this is one of the causes of hypertension. Thus, the development of specialized food products for people suffering from obesity and intestinal dysbiosis, as well as developing on the background of arterial hypertension, is demanded. Such products should be useful for health and do not cause harm to the human body. In this regard, it is not surprising that the modern market of products of specialized, functional, therapeutic and preventive nature consists of $65 \%$ enriched dairy products, among which the most popular are fermented milk products. They are easily absorbed by the 
body, improve digestion, stimulate the secretory activity, normalize intestinal activity, have antibacterial properties contained active lactic bacteria to prevent the development of intestinal pathogenic and putrefactive microorganisms $[6 ; 7]$.

Enriched with vegetable ingredients dairy products are aimed at satisfying the nutritional status and also have a number of therapeutic and preventive benefits due to the content of vitamins, macroand microelements [8;9].

In this regard, the aim of the present investigation was to study the application possibilities of vegetable and prebiotic components in fermented milk products, as well as development of the technology of symbiotic fermented milk product and then a comprehensive assessment of its quality.

\section{Materials and Methods}

\section{The samples of raw materials and the production technology}

As food ingredients in the developed technology of dairy products amaranth flour, hawthorn fruit and grape seed oil as sources of dietary and biologically active substances of plant origin, together with the syrup of lactulose, as substances which stimulate the growth and biological activity of representatives of protective microflora are encouraged to use.

The objects of study are the traditional and enriched dairy products. Experimental production control samples allowed us to conduct a comprehensive evaluation of the quality according to the sensory properties, physico-chemical and microbiological indicators, vitamin-mineral and amino acid composition of fermented milk products.

To develop the technology of the enriched fermented milk product, it was necessary to determine the type of the starter culture, dose, method and process step of introducing functional supplements, temperature and time conditions of the production.

Three types of starter cultures were examined in this study for a choice:

1. Starter, having in its composition Lactobacillus acidophilus, Streptococcus salivarius subsp. thermophilus, Lactococcus lactis subsp. diacetylactis;

2. Ferment on the basis of the kefir grain microflora: kefir yeast, Lactococcus lactis, Streptococcus salivarius subsp. thermophilus, Leuconostoc mesenteroides, Lactobacillus acidophilus, Bifidobacterium lactis, Lactobacillus delbrueckii ssp. Bulgaricus, Lactococcus lactis ssp. lactis;

3. Sourdough, consisting of the same species and strains of probiotic bacteria: Streptococcus salivarius subsp. thermophiles, Lactococcus lactis ssp. lactis, Lactobacillus acidophilus, Lactobacillus helveticus, Propionibacterium freudenreichii subsp. Shermanii.

The flow sheet of the fermented milk product is shown in Fig. 1, there:

- $X_{1}=$ sensory properties: $X_{1.1}=$ appearance and consistency, $X_{1.2}=$ taste and smell, $X_{1.3}=$ color;

- $X_{2}=$ physical and chemical properties: $X_{2.1}=$ titratable acidity, $X_{2.2}=$ temperature, $X_{2.3}=$ density, $X_{2.4}=$ mass fraction of fat, $X_{2.5}=$ mass fraction of protein, $X_{2.6}=$ mass fraction of dry substances, $X_{2.7}=$ the degree of frequency, $X_{2.8}=$ phosphatase, $X_{2.9}=$ weight.

- $X_{3}=$ microbiological indicators: $X_{3.1}=$ somatic cells, $X_{3.2}=$ CGB (coliforms), $X_{3.3}=$ QMAFAnM,$\quad X_{3.4}=$ Staphylococcus $S$. aureus, $X_{3.5}=$ pathogenic microorganisms (including Salmonella), $X_{3.6}=$ yeast, $X_{3.7}=$ mildew, $X_{3.8}=$ lactic acid bacteria.

- $X_{4}=$ safety parameters: $X_{4.1}=$ toxic elements, $X_{4.2}=$ mycotoxins, $X_{4.3}=$ inhibiting substances, $X_{4.4}=$ pesticides, $X_{4.5}=$ radionuclides .

The laboratory tests determined the doses of the application of the functional ingredients (per $1000 \mathrm{~kg}$ of the mixture excluding losses). They were hawthorn fruit $50 \mathrm{~kg}(5.0 \%)$, amaranth flour 30 $\mathrm{kg}(3.0 \%)$, grape seed oil $10 \mathrm{~kg}(1 \%)$, lactulose syrup $0.5 \mathrm{~kg}(0.5 \%)$. The total weight of functional ingredients was $95 \mathrm{~kg}$ per $1000 \mathrm{~kg}$ of the mixture. The starter was added at the rate of $3.0 \%$, i.e. $30 \mathrm{~kg}$ per $1000 \mathrm{~kg}$ of the mixture.

The recipes of fermented milk products were the following (Fig. 2). 


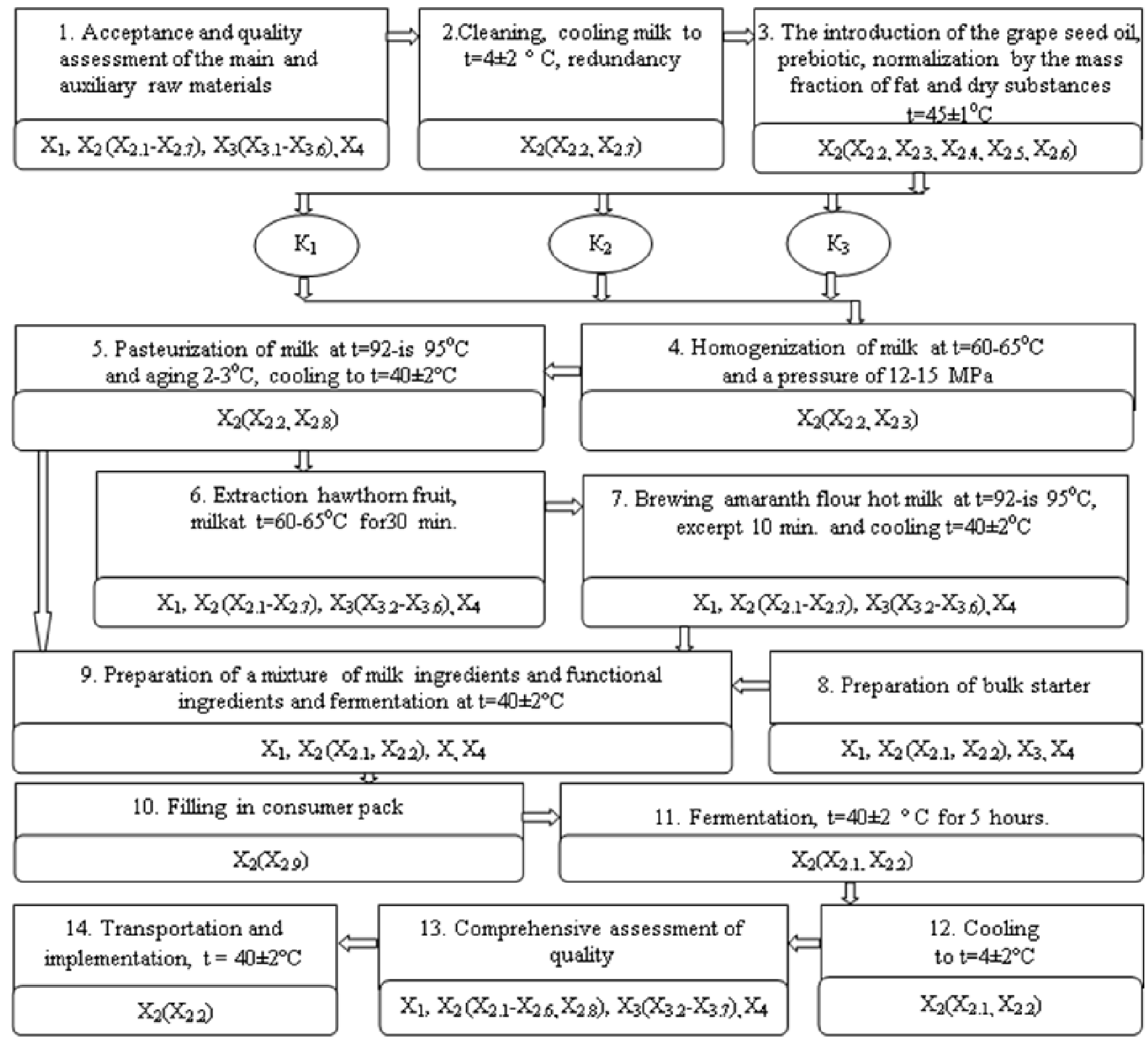

Fig. 1. Flow sheet of fermented milk products (thermostatic method): $K_{1}=$ normalized mixture ( $1.5 \%$ fat content); $K_{2}=$ normalized mixture ( $2.5 \%$ fat content); $K_{3}=$ normalized mixture $(3.5 \%$ fat content)

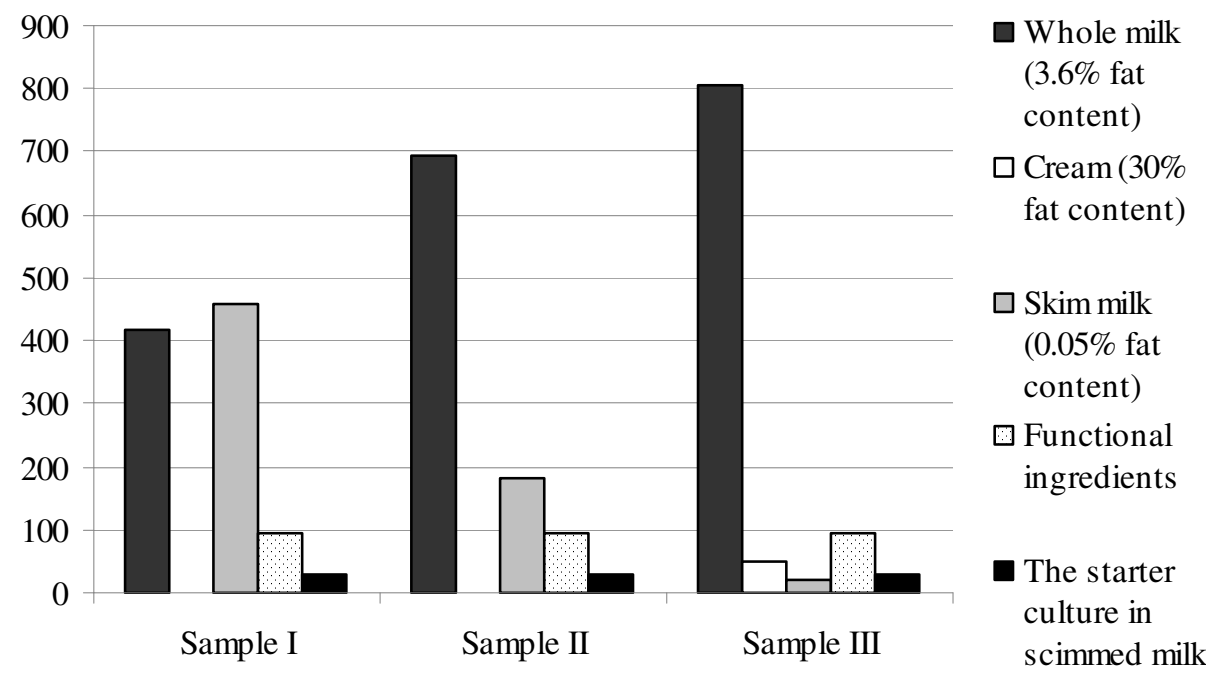

Fig. 2. Recipes of fermented milk products, where Sample I (1.5\% fat content), Sample II ( $2.5 \%$ fat content) and Sample III (3.5\% fat content) are given in $1 \mathrm{~kg}$ per $1000 \mathrm{~kg}$ mixture excluding losses 


\section{Analysis of the finished product characteristics}

Thus, the technology of production of a functional fermented milk product by a thermostatic method has been developed, which provided for the content of weight fat fraction in the finished product to be $1.5 \%, 2.5 \%$ and $3.5 \%$. Further studies (integrated quality assessment) were carried out on the samples with a $2.5 \%$ mass fraction of fat (Sample II) for both the traditional product (control) and for the enriched product (experimental).

The tasks of the experiment were to determine the sensory properties, physical-chemical and microbiological characteristics of the finished product. For these purposes, the standard and conventional techniques that satisfy the objectives of the study were used. Each measurement was performed in triplicate. Physical and chemical characteristics of the fermented milk products developed were determined in accordance with the requirements of the Technical regulations of the Customs Union "On safety of milk and dairy products" (TR TS 033/2013). Sensory analysis of the developed enriched products was carried out in accordance with GOST R ISO 22935-2-2011 "Milk and milk products".

In accordance with the GOST R 51303-2013 "Trade. Terms and definitions", the consumer properties of an item of goods are understood as properties of a product, which are manifested when they are used by the consumer in the process of satisfying his or her needs. Every item of goods has a set of properties, but only the properties that are able to satisfy certain needs and make the product useful for a human are related to consumer properties. Each product has many properties that can manifest in its formation or consumption. The properties of the product, which determine its usefulness in the process of consumption, are called consumer properties. We have identified the following consumer indicators that characterize the quality of products: sensory (appearance, consistency, colour and flavour), physicochemical (mass fraction of fat, protein and carbohydrates and vitamin and mineral compositions) as well as biological value (amino acid composition). To bring them to a single unit of measurement, a five-point scale was used, which allowed estimating the most important indices of consumer properties for experts. In this case, indicators that can be used in the sensory analysis of fermented milk products to calculate scores were applied as criteria. To evaluate the physicochemical parameters, vitamin, amino acid and mineral compositions, we developed an evaluation scale (Appendix 1).

Sensory analysis. Part 2. "Recommended methods for sensory evaluation" and GOST R ISO 22935-3-2011 "Milk and milk products. Sensory analysis. Part 3.Guidance on a method for evaluation of compliance with product specifications for sensory properties by scoring". Microbiological characteristics of the developed milk products were determined in accordance with the requirements of GOST 32901-2014 "Milk and milk products. Methods of microbiological analysis".

The amino acid composition was analyzed using a capillary electrophoresis system "KAPEL®105M" (Lumeks, Russia); the content of vitamins was determined on a chromatograph "Agilent 1200 Series" (Agilent Technologies, USA) by the high-performance liquid chromatography (HPLC). Determination of the chemical elements concentration in fermented milk products was performed on the quadrupole mass spectrometer Elan 9000 (PerkinElmer Instruments LLC, USA, by the inductively coupled plasma mass spectrometry: MS-ICP) and on the atomic emission spectrometer Optima 200 DK (PerkinElmer Instruments LLC, USA, by the atomic-emission spectrometry with inductively coupled plasma: NPP-ISP).

\section{The calculation of the nutritional and biological values}

The nutritional value $(N V)$ was estimated in accordance with the following formula (1):

$$
N \mathrm{~V}, \mathrm{kcal} / 100 \mathrm{~g}=4 \cdot P+9 \cdot F+4 \cdot C,
$$

where $P$ - percentage of protein, $\%$;

$F$ - percentage of fat, $\%$;

$C$ - percentage of carbohydrates, $\%$.

The amino-acid score $(A A S)$ was calculated as follows (2):

$$
A A S, \%=\frac{\text { Evaluated protein amino acid content }(\mathrm{g} / 100 \mathrm{~g} \text { protein })}{\text { FAO scoring model amino acid content }(\mathrm{g} / 100 \mathrm{~g} \text { protein })} \cdot 100 .
$$


The coefficient of amino-acid score difference (CAAS) - by the following formula (3):

$$
C A A S, \%=\frac{\sum\left(C_{i}-C_{\text {min }}\right)}{n},
$$

where $C_{i}$ - excess of amino-acid score, $\%$;

$C_{\min }$ - minimum score of essential amino acids of evaluated protein relative to the physiological norm (FAO scoring model amino acid content), \%;

$\sum\left(C_{i}-C_{\text {min }}\right)=\triangle A A S$

$n$ - number of essential amino acids.

The biological value $(B V)$ was calculated by the following formula (4):

$$
B V, \%=100-C A A S \text {. }
$$

To assess the balance of essential amino acids with respect to the reference protein, the utility $K_{i}$ coefficient was calculated (5).

$$
K_{i}=\frac{A S_{\min }}{A S_{i}},
$$

where $A S_{i}-$ amino acid score of the i-indispensable amino acid in the product;

$A S_{\min }-$ amino acid score of the first limiting amino acid in this product.

The utility coefficient of the i-indispensable amino acid $\left(A_{i}\right)$ was used to calculate the utility coefficient of the amino acid composition $(U)$, which was a numerical characteristic that reflected the balance of essential amino acids with respect to the standard $\left(A_{i S T}\right)$ :

$$
U=\frac{\sum_{i=1}^{n}\left(A_{i} K_{i}\right)}{\sum_{i=1}^{n} A_{i} s t} .
$$

\section{Statistical data processing}

The experimental data were analyzed by the Statistica 10.0 package using conventional techniques. The threshold of 0.05 was considered a minimum threshold of the significance of differences [10].

The MS Office 2010 was used for the graphical interpretation of the digital data.

\section{Results and Discussion}

The authors studied the composition and consumer properties of hawthorn fruit, amaranth flour, grape seed oil and lactulose. The results of studies of hawthorn suggest that the fruits have high sensory properties, contain a large amount of carbohydrates, fiber, vitamin $\mathrm{C}$ and vitamin $\mathrm{A}$, which helps strengthen the walls of blood vessels, the blood, the oxygen saturation in the blood and protect blood vessels against the negative effects of free radicals and high content of potassium and calcium supports a stable cardiac activity and the excretion of fluid from the body [11].

The amaranth flour is dominated by proteins and carbohydrates, it is rich in vitamins and minerals. B vitamins in excess of the value of other vitamins play an important role in the regulation of carbohydrate, fat, mineral and water metabolism; improve blood circulation and the gastrointestinal tract. The taste and smell of amaranth flour, given the developed product is light, pleasant aroma with a hint of walnut [12].

The grape seed oil has a high content of essential, polyunsaturated acids linoleic and oleic, which help reduce cholesterol, prevent hypertension and heart failure [13].

The syrup of lactulose was selected as "Bifidus factor". Lactulose (its content in the syrup is $42.0 \%$ ) is a disaccharide having useful physiological properties, it is an ideal nutrient medium for 
bifidobacteria, lactobacilli, stimulating their growth and activity, thus inhibiting the proteolytic flora of a thick intestine [14].

Thus, the obtained results of analysis of phytocomponents and syrup of lactulose indicate that the selected ingredients have a high nutritional and biological value, are biologically active substances, which can act as functional raw materials.

The study of the three types of starter cultures indicated in the section "Materials and Methods" found that the most harmonious was the fermented milk product produced using Starter III. Two other types of the starter gave the product a disharmonious flavour during the fermentation process, so Starter III (Streptococcus thermophiles, Lactococcus lactis, Lactobacillus acidophilus, Lactobacillus helveticus, Propionibacterium freudenreichii) was used in the production technology. The study of the relationship between the starter microflora and the acid production in the experienced products showed that the increase of titratable acidity occurs consistently in all samples, but the process of ripening till clot formation and achievements of the acidity to $65-70^{\circ} \mathrm{T}$, in the sample using the third type of starter culture it occurs faster compared with other samples (within 4.5 hours), which saves heat and energy and allows to consider the suggested technology as the resource-saving. As the results of the sensory analysis show, the fermented milk product produced with the third type of leaven had the most harmonious characteristics. The other two types of starters in the fermentation process give the product a discordant taste and smell, so in the future the third type of leaven will be used.

The symbiotic product has a more harmonious appearance than the traditional: a clean dairy flavor and smell with a pleasant aroma and sweet taste of vegetable ingredients, color creamy, uniform throughout the mass caused by the color made additives (Table 1).

Table 1

Integrated quality assessment of control and enriched samples (mean \pm s.e.m.)

\begin{tabular}{|c|c|c|}
\hline Indices & $\begin{array}{l}\text { Traditional fermented milk } \\
\text { product, Control Sample }\end{array}$ & $\begin{array}{c}\text { Enriched fermented milk } \\
\text { product, Test Sample }\end{array}$ \\
\hline Appearance and consistency & $\begin{array}{l}\text { Homogeneous, thick with } \\
\text { undisturbed clot }\end{array}$ & $\begin{array}{c}\text { Dense, homogeneous } \\
\text { consistency with undisturbed } \\
\text { clot, with a few patches of } \\
\text { amaranth flour }\end{array}$ \\
\hline Taste and smell & $\begin{array}{l}\text { Pure, sour-milk taste and } \\
\text { smell }\end{array}$ & $\begin{array}{l}\text { Pure, sour-milk taste and smell } \\
\text { with a pleasant taste and } \\
\text { aroma of the added amaranth } \\
\text { flour and some sweet flavor of } \\
\text { hawthorn fruit }\end{array}$ \\
\hline Colored & $\begin{array}{l}\text { Milky white, uniform } \\
\text { throughout the mass }\end{array}$ & $\begin{array}{l}\text { Creamy, uniform throughout } \\
\text { the mass }\end{array}$ \\
\hline Weight fraction of fat, $\%$ & $2.5 \pm 0.09$ & $2.5 \pm 0.07^{\mathrm{ns}}$ \\
\hline Weight fraction of protein, $\%$ & $2.8 \pm 0.04$ & $3.0 \pm 0.05^{\mathrm{c}}$ \\
\hline $\begin{array}{l}\text { Weight fraction of } \\
\text { carbohydrates, } \%\end{array}$ & $4.0 \pm 0.07$ & $5.2 \pm 0.11^{\mathrm{a}}$ \\
\hline Titratable acidity, ${ }^{\circ} \mathrm{T}$ & $85 \pm 0.58$ & $86 \pm 0.32^{\text {ns }}$ \\
\hline $\begin{array}{l}\text { Lactic acid microorganisms } \\
\text { amount, CFU per g, not less than } \\
\left(10^{7}\right)\end{array}$ & 1.6 & 20.0 \\
\hline Nutritional value, kcal $100 \mathrm{~g}^{-1}$ & $49.7 \pm 0.26$ & $55.3 \pm 0.33^{\mathrm{a}}$ \\
\hline
\end{tabular}

s.e.m. $=$ standard error of mean; $n s=$ not significant; $p=$ probability; ${ }^{a} p<0.001 ;{ }^{c} p<0.05$ compared to the control sample

Analysis of the physico-chemical parameters of the traditional and symbiotic products showed that the mass fraction of protein symbiotic product exceeded the value of the control sample $(0.2 \%$, $p<0.05)$. Also in the enriched product the mass fraction of carbohydrates increased $(1.2 \%$, $p<0.001$ ), which is associated with a high content of carbohydrates in functional ingredients. 
Microbiological characteristics of traditional and enriched products showed that the number of yeast and mold cells does not exceed the values regulated in the Technical regulations of the Customs Union "On safety of milk and dairy products" for the requirements for this group of dairy products. Pathogens, such as bacteria of group Escherichia coli, Staphylococus aureus and bacteria of the genus Salmonella in the samples of fermented milk products were not detected. The number of lactic acid microorganisms in the test sample exceeds as standardized, and the importance of traditional fermented milk product, which indicates the high physiological value of the developed product (enriched sample).

Table 1 also shows that enrichment of the fermented milk product with the proposed functional components increased its nutritional value by $11.3 \%(p<0.001)$.

The obtained values of the essential amino acid composition indicate that the enriched product by $26.1 \mathrm{mg} 1 \mathrm{~g}^{-1}$ exceeds the essential amino acid content in the traditional product $(p<0.001)$; the content of all amino acids - by $61.1 \mathrm{mg}^{-1} \mathrm{~g}^{-1}(p<0.001)$, including the amount of the nonessential amino acids (on $35.0 \mathrm{mg} 1 \mathrm{~g}^{-1}$ compared with a traditional drink, $p<0.001$ ). Among the essential amino acids in the greatest quantity in fermented milk products are leucine $\left(62.6 \mathrm{mg} 1 \mathrm{~g}^{-1}\right)$, lysine $\left(41.0 \mathrm{mg} 1 \mathrm{~g}^{-1}\right)$ and valine $\left(38.2 \mathrm{mg} 1 \mathrm{~g}^{-1}\right)$. Some essential amino acids in the enriched beverage significantly exceeded similar compared with a traditional product $(\mathrm{mg}$ per $1 \mathrm{~g})$ : valine - by 1.2 $(p<0.01)$, leucine - by $2.4(p<0.01)$, isoleucine - by $7.2(p<0.001)$, lysine - by $5.0(p<0.001)$, methionine+cystine - by $1.3(p<0.01)$, phenylalanine - by $6.0(p<0.001)$, threonine - by 2.4 $(p<0.001)$.

Among the nonessential amino acids contained in the enriched symbiotic product in the greatest quantity were the following ( $\mathrm{mg}$ per $1 \mathrm{~g}$ ): glutamic acid -92.0 , proline -39.2 , serine -29.9 . The highest deviations (mg per $1 \mathrm{~g}$ ) compared to the control sample were for glutamic acid - by 15.6 $(p<0.001)$, arginine - by $7.1(p<0.001)$, and proline - by $6.2(p<0.001)$.

The results of amino acid analysis are presented in Table 2.

Table 2

Amino acid composition of fermented milk products (mean \pm s.e.m.), mg per $1 \mathrm{~g}$

\begin{tabular}{|c|c|c|c|}
\hline Indices & $\begin{array}{c}\text { Reference } \\
\text { protein, FAO } \\
{[\mathbf{1 5}]}\end{array}$ & $\begin{array}{c}\text { Traditional fermented } \\
\text { milk product, Control } \\
\text { Sample }\end{array}$ & $\begin{array}{c}\text { Enriched fermented } \\
\text { milk product, Test } \\
\text { Sample }\end{array}$ \\
\hline Valine & 40 & $37.0 \pm 0.21$ & $38.2 \pm 0.14^{\mathrm{b}}$ \\
\hline Lysine & 48 & $36.0 \pm 0.10$ & $41.0 \pm 0.16^{\mathrm{a}}$ \\
\hline Methionine+cystine & 23 & $13.5 \pm 0.15$ & $14.8 \pm 0.21^{\mathrm{b}}$ \\
\hline Phenylalanine & 41 & $19.6 \pm 0.33$ & $25.6 \pm 0.24^{\mathrm{a}}$ \\
\hline Threonine & 25 & $15.6 \pm 0.18$ & $18.0 \pm 0.12^{\mathrm{a}}$ \\
\hline Isoleucine & 30 & $27.8 \pm 0.13$ & $35.0 \pm 0.09^{\mathrm{a}}$ \\
\hline Tryptophan & 6,6 & $6.4 \pm 0.22$ & $7.0 \pm 0.37^{\mathrm{ns}}$ \\
\hline Leucine & 61 & $60.2 \pm 0.26$ & $62.6 \pm 0.24^{\mathrm{b}}$ \\
\hline
\end{tabular}

s.e.m. $=$ standard error of mean; ns $=$ not significant; $\mathrm{p}=$ probability; ${ }^{a} p<0.001 ;{ }^{\mathrm{b}} p<0.01$

compared to the control sample

According to the data obtained, the limiting amino acid in the samples of fermented milk products was phenylalanine. So, the amino acid score was $62.4 \%$ in the enriched product (test) and $47.8 \%$ in the traditional product (control). The enriched product had higher indices for essential amino acids, some were close to the reference ones (valine). In the enriched product, isoleucine exceeded the standard, i.e. "ideal" protein, by $5.0 \%$, leucine by $2.4 \%$ and slightly tryptophan by $0.6 \%$.

In Table 3 it is shown that the coefficient of amino-acid score difference of the traditional product (control) was $26.89 \%$, and the biological value was $73.11 \%$. The coefficient of amino-acid score difference of the enriched product (test) was $22.94 \%$ and the biological value was $77.06 \%$, which indicated high biological value of the enriched fermented milk product.

According to the calculations, the utility coefficient of the amino acid composition $(U)$ of the enriched product was 0.60 , exceeding the value of the traditional product by 0.14 . This indicates a greater degree of balance of the amino acid composition of the enriched fermented milk product with 
respect to the traditional (control) one, which indicated the possibility of more rational use by the body.

Table 3

Biological value indicators of fermented milk products

\begin{tabular}{|c|c|c|c|c|c|c|c|c|c|c|c|c|}
\hline \multirow{2}{*}{ Indices } & \multicolumn{6}{|c|}{$\begin{array}{l}\text { Traditional fermented milk } \\
\text { product, Control Sample }\end{array}$} & \multicolumn{6}{|c|}{$\begin{array}{l}\text { Enriched fermented milk } \\
\text { product, Test Sample }\end{array}$} \\
\hline & $\begin{array}{c}\text { AAS } \\
\%\end{array}$ & $\triangle \mathrm{AAS}$ & $\underset{\%}{\text { CAAS, }}$ & BV & $\mathbf{K}_{\mathrm{i}}$ & $\mathbf{U}$ & $\begin{array}{c}\text { AAS, } \\
\%\end{array}$ & $\triangle \mathrm{AAS}$ & $\underset{\%}{\text { CAAS, }}$ & BV & $\mathbf{K}_{\mathrm{i}}$ & $\mathbf{U}$ \\
\hline Valine & 92.5 & 44.7 & \multirow{8}{*}{26.89} & \multirow{8}{*}{73.11} & 0.51 & \multirow{8}{*}{0.46} & 95.5 & 33.07 & \multirow{8}{*}{22.94} & \multirow{8}{*}{77.06} & 0.65 & \multirow{8}{*}{0.60} \\
\hline Lysine & 75.0 & 27.2 & & & 0.63 & & 85.4 & 22.97 & & & 0.73 & \\
\hline Methionine & 58.6 & 10.8 & & & 0.81 & & 64.3 & 1.87 & & & 0.97 & \\
\hline Phenylalanine & 47.8 & - & & & 1 & & 62.43 & - & & & 1 & \\
\hline Threonine & 62.4 & 14.6 & & & 0.76 & & 72.9 & 10.6 & & & 0.85 & \\
\hline Isoleucine & 92.6 & 44.8 & & & 0.51 & & 116.6 & 54.17 & & & 0.53 & \\
\hline Tryptophan & 96.96 & 49.16 & & & 0.49 & & 106.06 & 43.63 & & & 0.58 & \\
\hline Leucine & 98.6 & 50.8 & & & 0.48 & & 102.6 & 40.17 & & & 0.60 & \\
\hline
\end{tabular}

We have also investigated the vitamin composition, the results are presented in Fig. 3. The analysis of the figure showed that the content of vitamins in the enriched dairy product was higher than in the control. So the concentrations of vitamins A, D, E and PP, in the enriched product were higher than in the control (per $1 \mathrm{~g})$ by $20.0 \mu \mathrm{g}(p<0.01), 0.01 \mu \mathrm{g}(p<0.05), 60.0 \mu \mathrm{g}(p<0.01)$ and $70.0 \mu \mathrm{g},(p<0.05)$ respectively. As well as concentration of B-group vitamins in the enriched product was higher than in the control (vitamin $\mathrm{B}_{1}-$ by $20.0 \mu \mathrm{g}, p<0.05 ; \mathrm{B}_{2}-$ by $30.0 \mu \mathrm{g}, p<0.05 ; \mathrm{B}_{5}-$ by $20.0 \mu \mathrm{g}, p<0.05 ; \mathrm{B}_{6}-$ by $20.0 \mu \mathrm{g}, p<0.05 ; \mathrm{B}_{12}-$ by $0.05 \mu \mathrm{g}(p<0.05)$.

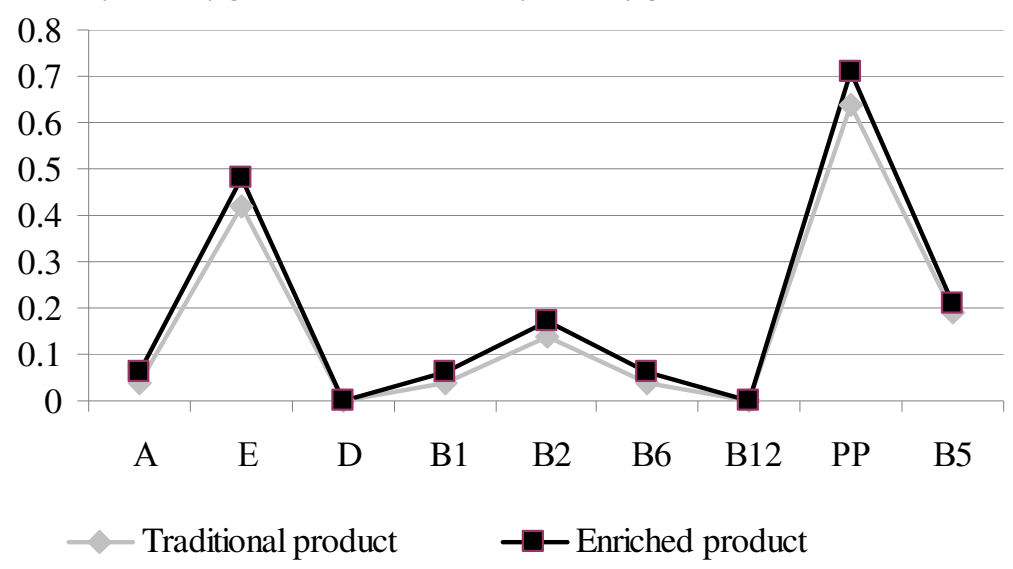

Fig. 3. Vitamin composition of samples, $\mathbf{m g}$

The need for vitamins is individual and depends largely on the energy costs, a person's weight, state of health, balance of power, the climate and time of the year. People consume food that contains a lot of vitamins every day, but still an insufficient number to maintain for themselves the vitamin balance [16]. However, the developed product allows to compensate for that deficiency partially (in percentages from the recommended daily intake): vitamin B2 -by $9.44 \%$; vitamin A - by $6.66 \%$; pantothenic acid - by $4.20 \%$; vitamin PP - by $3.55 \%$.

The biologically active properties of functional food are interconnected with its mineral composition. The results of this implementation are presented in Fig. 4 (A and B).

A large amount of mineral substances was found in the developed fermented milk product. The increase in the content of mineral substances in the enriched sample was due to the introduction of phytocomponents and was higher than similar in the control (per $100 \mathrm{~g}$ ) by $5.27 \mathrm{mg}$ for sodium $(p<0.05), 5.84 \mathrm{mg}$ for potassium $(p<0.01), 5.44 \mathrm{mg}$ for calcium $(p<0.01), 6.68 \mathrm{mg}$ for phosphorus $(p<0.01), 3.66 \mathrm{mg}$ for magnesium $(p<0.001), 10.84 \mu \mathrm{g}$ for zinc $(p<0.01), 18.55 \mu \mathrm{g}$ for iron $(p<0.001), 4.94 \mu \mathrm{g}$ for copper $(p<0.05), 2.92 \mu \mathrm{g}$ for manganese $(p<0.01)$ and $0.2 \mu \mathrm{g}$ for iodine $(p<0.05)$. 
a)

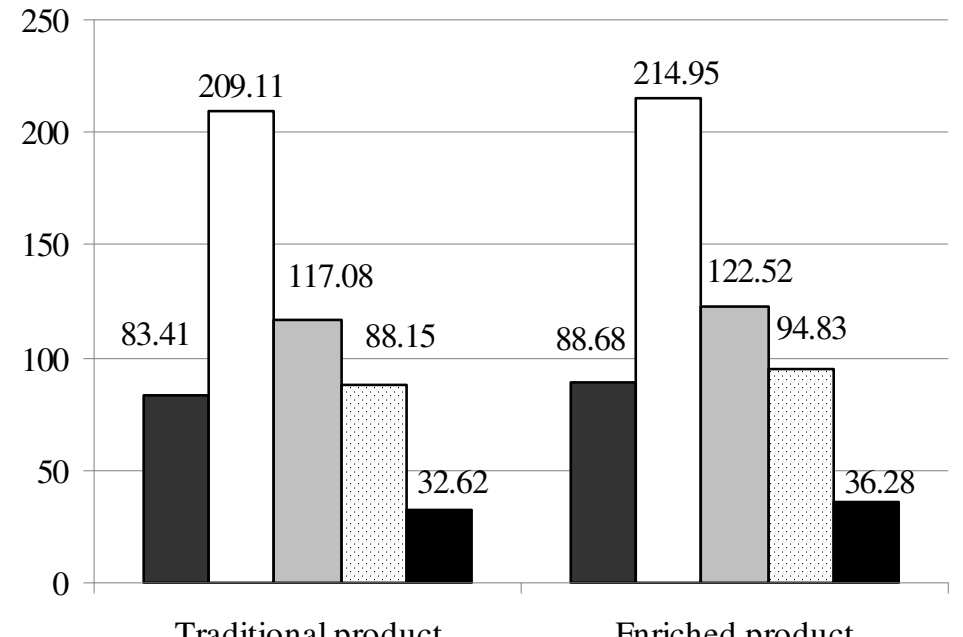

b)

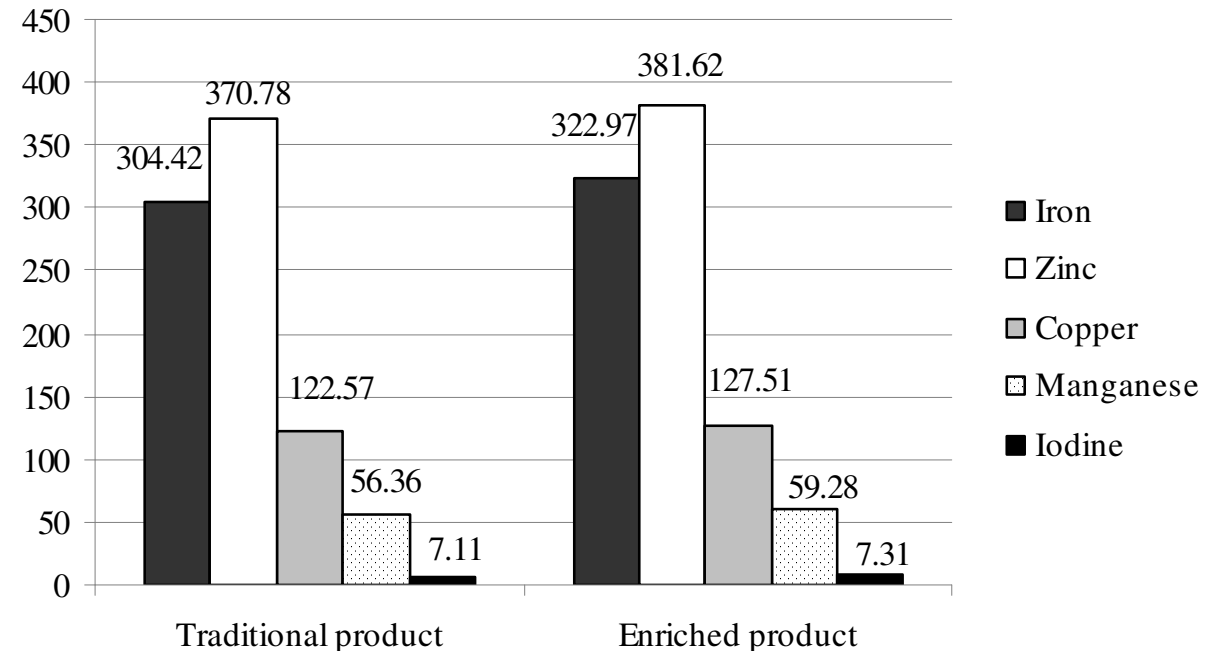

Fig. 4. Mineral composition of samples: a - macroelements content (mg), $\mathrm{b}$ - trace elements content $(\mu \mathrm{g})$

The developed product allows to compensate for mineral deficiency partially (in percentages from the recommended daily intake): calcium - by $12.2 \%$; phosphorus - by $11.75 \%$; potassium - by $8.56 \%$. Trace elements are found in the body in much smaller quantities, but still play an important role in normal functioning of the body. Copper content in the developed product was increased by $12.7 \%$ of the daily requirement; iodine - by $4.87 \%$; iron - by $3.22 \%$.

To characterize the consumer properties of the developed fermented drink compared with the traditional product a five-point rating scale was used, including sensory evaluation, investigation of physico-chemical parameters, vitamin, mineral and amino acid compositions. The results of the listed consumer characteristics assessment are presented in profilogram (Fig. 5).

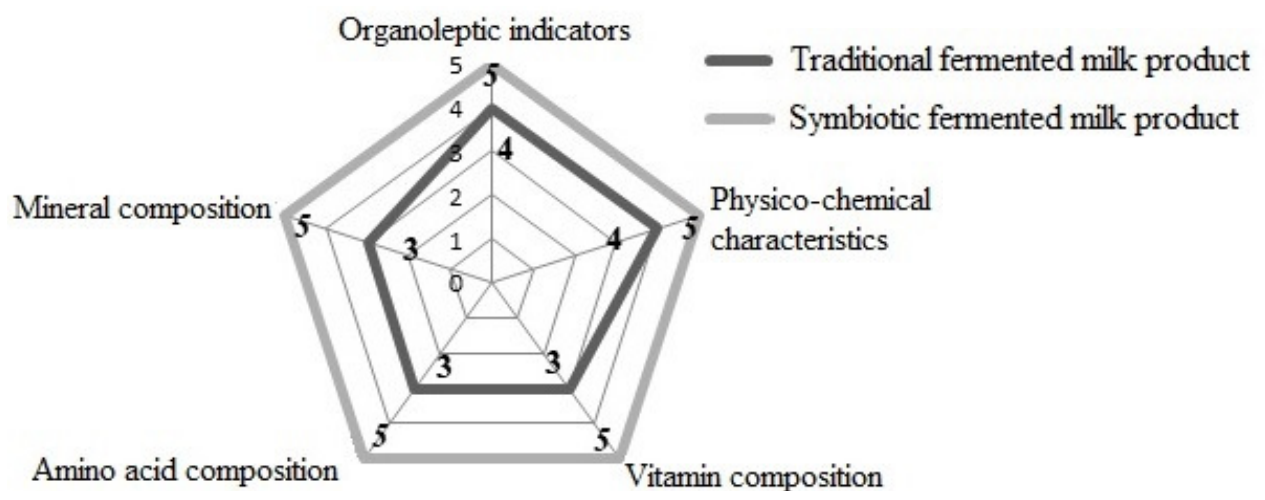

Fig. 5. Consumer qualities profilogram of fermented milk product compared with control 
As it can be seen from the figure, the enriched milk product possesses high consumer properties, what makes it possible to predict the customer demand among the population in the future.

\section{Conclusions}

The technology of a symbiotic product with phytocomponents based on the thermostatic method was developed. The resulting data revealed that the suggested plant raw materials in combination with syrup of lactulose are the source of vitamins and mineral substances, have a high nutritional and biological value, so it is possible to use them in the production of functional fermented milk products as a balanced complex of biologically active ingredients.

\section{Acknowledgements}

The authors are grateful to the Russian Federation Federal Agency for Scientific Organizations (FASO Russia) for the financial support in the implementation of this research according to the state assignment of NIIMMP, Project № AAAA-A17-117033110080-5.

\section{References}

[1] FAO, IFAD, UNICEF, WFP and WHO. The State of Food Security and Nutrition in the World. Building resilience for peace and food security. Rome: FAO, 2017. $132 \mathrm{p}$.

[2] The order of the Government of the Russian Federation of 25.10.2010 № 1873-R "Concept of the state policy of the Russian Federation in the field of healthy nutrition of the population for the period till 2020".

[3] Gorlov I.F., Giro T.M., Sitnikova O.I., Slozhenkina M.I., Zlobina E.Y., Karpenko E.V. 2016. New functional products with chickpeas: Reception, functional properties. American Journal of Food Technology. 11 (6), pp. 273-281. DOI: 10.3923/ajft.2016.273.281.

[4] Smith K.B., Smith M.S. Obesity Statistics. Primary care, vol. 43, 2016, 121 p. DOI: 10.1016/j.pop.2015.10.001

[5] Cencic A., Chingwaru W. The Role of Functional Foods, Nutraceuticals, and Food Supplements in Intestinal Health. Nutrients, vol. 2, 2010, pp. 611-625. DOI: 10.3390/nu2060611.

[6] Tamime A.Y. Fermented milks: a historical food with modern applications - a review. European Journal of Clinical Nutrition, vol. 56, 2002, pp. S2-S15 (4). DOI: 10.1038/sj.ejcn.1601657.

[7] Titov E.I., Tikhomirova N.A., Ionova I.I., Gorlov I.F., Slozhenkina M.I., Mosolova N.I., Zlobina E.Y. Growth stimulating effect of bovine milk lactoferrin on dermal cells and probiotic bacteria. Emirates Journal of Food and Agriculture, vol. 28, 2016, pp. 540-546. DOI: 10.9755/ejfa.201506-447.

[8] Abuajah C.I., Ogbonna A.C., Osuji C.M. Functional components and medicinal properties of food: a review. Journal of Food Science and Technology-Mysore, vol. 52, 2015, pp. 2522-2529. DOI: 10.1007/s13197-014-1396-5.

[9] Slozhenkina M., Serova O., Vodolazkova M., Zlobina E. Functional and technological characteristics of new cheese product with vegetable and prebiotic components. Proceedings of 16th International Scientific Conference "Engineering for Rural Development", May 24-26, 2017, Jelgava, Latvia, pp. 393-401. DOI: 10.22616/ERDev2017.16.N078. 2017.

[10] Johnson R.A., Bhattacharyya G.K. Statistics principles and methods. Sixth edition. USA: John Wiley \& Sons, 2010. 706 p.

[11] Yu Q., Duan Z.H. Research Progress in the Processing and Exploitation of Hawthorn. Proceedings of Joint 2016 International Conference on Social Science and Environmental Science (SSES 2016) and International Conference on Food Science and Engineering (ICFSE 2016), Oct 15-16, 2016, Guangzhou, Peoples R China, pp. 395-403.

[12] Sanz-Penella J.M., Wronkowska M., Soral-Smietana M., Haros M. Effect of whole amaranth flour on bread properties and nutritive value. LWT-Food Science and Technology, vol. 50, 2013, pp. 679-685. DOI: 10.1016/j.lwt.2012.07.031.

[13] Shinagawa F.B., de Santana F.C., Torres L.R.O., Mancini J. Grape seed oil: a potential functional food? Food Science and Technology, vol. 35, 2015, pp. 399-406. DOI: 10.1590/1678-457X.6826. 
[14] Ait-Aissa A., Aider M. Lactulose: production and use in functional food, medical and pharmaceutical applications. Practical and critical review. International Journal of Food Science and Technology, vol. 49, 2014, pp. 1245-1253. DOI: 10.1111/ijfs.12465.

[15] Dietary protein quality evaluation in human nutrition: Report of an FAO Expert Consultation. Rome: FAO, 2013. 76 p. [online] [16.03.2018]. Available at: http://www.fao.org/3/a-i3124e.pdf.

[16]Dickinson A., Blatman J., El-Dash N., Franco J.C. Consumer Usage and Reasons for Using Dietary Supplements: Report of a Series of Surveys. Journal of the American College of Nutrition, vol. 33, 2014, pp. 176-182. DOI: 10.1080/07315724.2013.875423.

Appendix 1

Indices on the evaluation scale for fermented milk products

\begin{tabular}{|c|c|c|c|c|c|}
\hline \multirow{2}{*}{ Name } & \multicolumn{5}{|c|}{ Evaluation scale, point } \\
\hline & 5 & 4 & 3 & 2 & 1 \\
\hline $\begin{array}{l}\text { Physicochemica } \\
1 \text { indices }\end{array}$ & $\begin{array}{l}\text { The product } \\
\text { corresponds to } \\
\text { the data } \\
\text { obtained in the } \\
\text { study of the } \\
\text { weight fraction } \\
\text { of fat, protein } \\
\text { and } \\
\text { carbohydrates. } \\
\text { It has high } \\
\text { indices. } \\
\text { Titrated acidity } \\
\text { meets the } \\
\text { requirements } \\
\text { of the } \\
\text { regulatory } \\
\text { documents. } \\
\text { Phosphatase is } \\
\text { absent. }\end{array}$ & $\begin{array}{l}\text { The product has one } \\
\text { of the indices below, } \\
\text { obtained in the study } \\
\text { of the weight fraction } \\
\text { of fat, protein and } \\
\text { carbohydrates, and } \\
\text { meets the GOST } \\
\text { requirements. The } \\
\text { titrated acidity meets } \\
\text { the requirements of } \\
\text { the regulatory } \\
\text { documents. } \\
\text { Phosphatase is } \\
\text { absent. }\end{array}$ & $\begin{array}{l}\text { The product has two } \\
\text { of the indices below, } \\
\text { obtained in the study } \\
\text { of the weight fraction } \\
\text { of fat, protein and } \\
\text { carbohydrates, and } \\
\text { meets the GOST } \\
\text { requirements. The } \\
\text { titrated acidity meets } \\
\text { the requirements of } \\
\text { the regulatory } \\
\text { documents. } \\
\text { Phosphatase is } \\
\text { absent. }\end{array}$ & $\begin{array}{l}\text { The product has three } \\
\text { of the indices below, } \\
\text { obtained in the study } \\
\text { of the weight fraction } \\
\text { of fat, protein and } \\
\text { carbohydrates, and } \\
\text { meets the GOST } \\
\text { requirements. The } \\
\text { titrated acidity meets } \\
\text { the requirements of } \\
\text { the regulatory } \\
\text { documents. } \\
\text { Phosphatase is } \\
\text { absent. }\end{array}$ & $\begin{array}{l}\text { The product has low } \\
\text { values in comparison } \\
\text { with the data obtained } \\
\text { in the study of the } \\
\text { weight fraction of fat, } \\
\text { protein and } \\
\text { carbohydrates, and } \\
\text { meets the GOST } \\
\text { requirements. The } \\
\text { titrated acidity meets } \\
\text { the requirements of the } \\
\text { regulatory documents. } \\
\text { Phosphatase is absent. }\end{array}$ \\
\hline $\begin{array}{l}\text { Vitamin } \\
\text { compositions }\end{array}$ & $\begin{array}{l}\text { The product } \\
\text { corresponds to } \\
\text { the data } \\
\text { obtained in the } \\
\text { study of the } \\
\text { vitamin } \\
\text { composition. It } \\
\text { has high values } \\
\text { of fat-soluble } \\
\text { and water- } \\
\text { soluble } \\
\text { vitamins. }\end{array}$ & $\begin{array}{l}\text { The product has } \\
\text { values lower by } 5 \% \\
\text { according to the data } \\
\text { obtained in the study } \\
\text { of the vitamin } \\
\text { composition. It has } \\
\text { high values of fat- } \\
\text { soluble and water- } \\
\text { soluble vitamins. }\end{array}$ & $\begin{array}{l}\text { The product has } \\
\text { values lower by } 10 \% \\
\text { according to the data } \\
\text { obtained in the study } \\
\text { of the vitamin } \\
\text { composition. }\end{array}$ & $\begin{array}{l}\text { The product has } \\
\text { values lower by } 15 \% \\
\text { according to the data } \\
\text { obtained in the study } \\
\text { of the vitamin } \\
\text { composition. }\end{array}$ & $\begin{array}{l}\text { The product has values } \\
\text { lower by } 20 \% \\
\text { according to the data } \\
\text { obtained in the study of } \\
\text { the vitamin } \\
\text { composition. }\end{array}$ \\
\hline $\begin{array}{l}\text { Aminoacid } \\
\text { composition }\end{array}$ & $\begin{array}{l}\text { The product } \\
\text { corresponds to } \\
\text { the data } \\
\text { obtained in the } \\
\text { study of the } \\
\text { amino acid } \\
\text { composition. It } \\
\text { has high values } \\
\text { of } \\
\text { interchangeabl } \\
\text { e and essential } \\
\text { amino acids }\end{array}$ & $\begin{array}{l}\text { The product has } \\
\text { values lower by } 5 \% \\
\text { according to the data } \\
\text { obtained in the study } \\
\text { of the amino acid } \\
\text { composition. It has } \\
\text { high values of } \\
\text { interchangeable and } \\
\text { irreplaceable amino } \\
\text { acids. }\end{array}$ & $\begin{array}{l}\text { The product has } \\
\text { values lower by } 10 \% \\
\text { according to the data } \\
\text { obtained in the study } \\
\text { of the amino acid } \\
\text { composition. }\end{array}$ & $\begin{array}{l}\text { The product has } \\
\text { values lower by } 15 \% \\
\text { according to the data } \\
\text { obtained in the study } \\
\text { of the amino acid } \\
\text { composition. }\end{array}$ & $\begin{array}{l}\text { The product has values } \\
\text { lower by } 20 \% \\
\text { according to the data } \\
\text { obtained in the study of } \\
\text { the amino acid } \\
\text { composition. }\end{array}$ \\
\hline $\begin{array}{l}\text { Mineral } \\
\text { compositions }\end{array}$ & $\begin{array}{l}\text { The product } \\
\text { corresponds to } \\
\text { the data } \\
\text { obtained in the } \\
\text { study of the } \\
\text { mineral } \\
\text { composition. It } \\
\text { has high values } \\
\text { of macro and } \\
\text { microelements. }\end{array}$ & $\begin{array}{l}\text { The product has } \\
\text { values lower by } 5 \% \\
\text { according to the data } \\
\text { obtained in the study } \\
\text { of the mineral } \\
\text { composition. It has } \\
\text { high values of macro } \\
\text { and microelements. }\end{array}$ & $\begin{array}{l}\text { The product has } \\
\text { values lower by } 10 \% \\
\text { according to the data } \\
\text { obtained in the study } \\
\text { of the mineral } \\
\text { composition. }\end{array}$ & $\begin{array}{l}\text { The product has } \\
\text { values lower by } 15 \% \\
\text { according to the data } \\
\text { obtained in the study } \\
\text { of the mineral } \\
\text { composition. }\end{array}$ & $\begin{array}{l}\text { The product has values } \\
\text { lower by } 20 \% \\
\text { according to the data } \\
\text { obtained in the study of } \\
\text { the mineral } \\
\text { composition. }\end{array}$ \\
\hline
\end{tabular}

